\title{
Effect of zinc supplementation on growth Hormone Insulin growth factor axis in short Egyptian children with zinc deficiency
}

\author{
Rasha T Hamza ${ }^{1 *}$, Amira I Hamed ${ }^{2+}$ and Mahmoud T Sallam ${ }^{3+}$
}

\begin{abstract}
Background: The relationship between zinc ( $\mathrm{Zn}$ ) and growth hormone-insulin growth factor (GH-IGF) system and how $\mathrm{Zn}$ therapy stimulates growth in children has not been clearly defined in humans. Thus, we aimed to assess GH-IGF axis in short children with Zn deficiency and to investigate the effect of Zn supplementation on these parameters.

Methods: Fifty pre-pubertal Egyptian children with short stature and Zn deficiency were compared to 50 age-, sex-, and pubertal stage- matched controls. All subjects were subjected to history, auxological assessment and measurement of serum Zn, IGF-1, insulin growth factor binding protein-3 (IGFBP-3); and basal and stimulated GH before and 3 months after Zn supplementation ( $50 \mathrm{mg} /$ day).

Results: After 3 months of $\mathrm{Zn}$ supplementation in $\mathrm{Zn}$-deficient patients, there were significant increases in height standard deviation score (SDS, $P=0.033)$, serum Zn ( $P<0.001)$, IGF-1 $(P<0.01)$, IGF-1 standard deviation score (SDS, $P<0.01)$ and IGFBP-3 $(P=0.042)$. Zn rose in all patients but reached normal ranges in $64 \%$, IGF-1 levels rose in $60 \%$ but reached normal ranges in $40 \%$ and IGFBP-3 levels rose in $40 \%$ but reached reference ranges in $22 \%$. Growth velocity (GV) SDS did not differ between cases and controls $(p=0.15)$ but was higher in GH-deficient patients than non-deficient ones, both having Zn deficiency $(p=0.03)$.

Conclusion: Serum IGF-1 and IGFBP-3 levels were low in short children with Zn deficiency, and increased after Zn supplementation for 3 months but their levels were still lower than the normal reference ranges in most children; therefore, Zn supplementation may be necessary for longer periods.
\end{abstract}

Keywords: Egyptian, Growth hormone, Insulin growth factor-1, Zinc

\section{Introduction}

Although $\mathrm{Zn}$ deficiency is a common nutritional problem around the world, especially in children in developing countries where diets have less $\mathrm{Zn}$ available, it is difficult to identify this problem. $\mathrm{Zn}$ is important for the metabolic activity of more than two hundred enzymes. It is essential for cell replication, and deoxyribonucleic acid (DNA) and protein synthesis. Zn deficiency is reported to be associated with impairment of growth, testicular functions, appetite,

\footnotetext{
* Correspondence: rashatarif_2000@hotmail.com

${ }^{\dagger}$ Equal contributors

'Department of Pediatrics, Ain Shams University, 36 Hisham Labib street, off Makram Ebeid street, Nasr City, Cairo, Egypt

Full list of author information is available at the end of the article
}

and sense of taste, delay in wound healing, immune resistance and memory. $\mathrm{Zn}$ deficiency interferes with the metabolism of thyroid hormones, androgens and growth hormone (GH). It is not known what mechanism is responsible for growth retardation in $\mathrm{Zn}$ deficiency and how $\mathrm{Zn}$ therapy stimulates growth in children [1].

The principal regulator of growth in the body is the GH-IGF system [2]. It appears that Zn supplementation has positive effects on growth and IGF-1 levels in various groups of $\mathrm{Zn}$-deficient children. However, the exact mechanism of $\mathrm{Zn}$ deficiency and the mechanism by which $\mathrm{Zn}$ supplementation affects GH secretion and IGF-1 levels is not well delineated. Furthermore, the effect of $\mathrm{Zn}$ supplementation on the GH-IGF axis in non Zn-deficient short

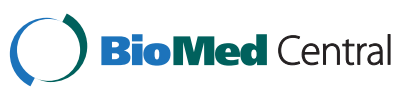


children is not known [3]. Some studies have reported positive effects of $\mathrm{Zn}$ supplementation on growth in various groups of Zn-deficient children [3-5]. However, in some studies, this effect was not observed [6,7].

With this background, we were stimulated to assess GH-IGF axis in short children with $\mathrm{Zn}$ deficiency and to investigate the effect of $\mathrm{Zn}$ supplementation on these parameters.

\section{Subjects and methods Study population}

This prospective case control study was conducted on 50 pre-pubertal Egyptian children with short stature and $\mathrm{Zn}$ deficiency [27 males (54\%), 23 females (46\%)] whose ages ranged between 3.2 and 10.9 years (mean age: $6.5 \pm 3.05$ years). All patients were shorter than expected for their chronological age and sex (height SDS $<-2$ ) [8]. Patients were recruited from Nile Hospital, Egyptian Health Insurance $(n=32)$ and the Pediatrics Outpatient Clinic, Children's hospital, Faculty of Medicine, Ain Shams University, Cairo, Egypt $(\mathrm{n}=18)$ during the period from the beginning of April 2010 to the end of August 2011. Cases were compared to 50 healthy age-, sex- and pubertal stage- matched children serving as controls who had normal serum Zn levels. They were 28 males (56 \%) and 22 females ( $44 \%$ ) whose ages ranged between 3.5 and 10.8 years (mean age: $6.7 \pm 2.05$ years). They were recruited from the Pediatrics Outpatient clinic, Children`s hospital, Faculty of Medicine, Ain shams University, Cairo, Egypt.

Children with chronic systemic diseases, bone dysplasias, dysmorphic syndromes, chronic malabsorption, other nutritional deficiencies, short stature with normal serum $\mathrm{Zn}$ levels $(>109 \mu \mathrm{g} / \mathrm{dl})$, other endocrine problems e.g hypothyroidism and history of long-term medications that might influence the GH-IGF axis were excluded from the study. In addition, all patients were not on GH therapy during the time of the study.

An informed written consent of participation in the study was signed by the parents or legal guardians of the studied subjects. This study was approved by the Bioethical Research Committee, Faculty of Medicine, Ain Shams University hospitals, Cairo, Egypt.

\section{Study measurements}

All studied children were subjected to:

- Medical history and clinical assessment: laying stress on therapeutic history, systemic examination and dysmorphic features.

- Auxological parameters: Height was measured to the nearest $1.0 \mathrm{~mm}$ with a Harpenden wall mounted stadiometer and weight to the nearest $0.1 \mathrm{~kg}$ on electronic scales together with calculation of height for age, weight for height and height velocity Standard Deviation Scores (SDSs) [8]. Body Mass Index (BMI) was calculated using the formula weight (in $\mathrm{kg}$ )/height ${ }^{2}$ (in meters) together with calculation of BMI SDS calculated from the age- and sex-specific reference values [9].

- Tanner pubertal staging: for assessment of pubertal status according to the standards of Tanner and Whitehouse (1976) [10]

- Laboratory assays: All blood samples were taken in the morning after an overnight fast for measurement of the following:

- Serum Zn which was measured by a spectrophotometric method after deproteinization of samples. The normal reference range ranged from109-167 ng/dl while serum $\mathrm{Zn}$ values below $109 \mu \mathrm{g} / \mathrm{dl}$ indicated $\mathrm{Zn}$ deficiency [11].

- Serum IGF-1 and IGFBP-3 that were measured using a solid phase, enzyme labeled chemiluminescent immunometric assay. Values were expressed as absolute values $(\mathrm{ng} / \mathrm{ml})$ and were also expressed as SDS for age and sex according to normal reference ranges of Elmlinger et al., 2004 [12]

- Basal and stimulated serum GH levels after insulin induced hypoglycemia, in which baseline $\mathrm{GH}$ and glucose samples were withdrawn and regular insulin was administered in a dose of 0.1 unit/kg intravenously and samples for measurement of $\mathrm{GH}$ and glucose were withdrawn at 30, 60, 90 and 120 minutes. Blood glucose must decrease by $50 \%$ of the initial value or to $<40 \mathrm{mg} \%$. In addition, $\mathrm{GH}$ provocation test by clonidine was done to confirm the diagnosis of growth hormone deficiency (GHD) in which a baseline $\mathrm{GH}$ sample was withdrawn and clonidine was administered in a dose of $5 \mu \mathrm{g} / \mathrm{kg}$ orally and samples for measurement of $\mathrm{GH}$ were withdrawn at 30, 60, 90 and 120 minutes. Normally, GH should rise to a peak of $\geq 10 \mathrm{ng} / \mathrm{ml}$ at any of the post-stimulatory samples. Patients with peak GH levels $<10 \mathrm{ng} / \mathrm{ml}$ by the 2 stimulatory tests were considered GH-deficient [13]. Serum GH concentrations were measured using commercial reagents (Pharmacia Diagnostics, Uppsala, Sweden) by a solid-phase, enzyme-labeled chemiluminiscent immunometric assay (by the Immulite, 2000 Analyzer, Siemens).

- Bone age (BA) was done by performing plain $\mathrm{X}$ ray left hand and wrist together with calculation of bone age SDS according to the standards of Greulich and Pyle [14]. 
Table 1 Descriptive clinical, laboratory and radiological data of studied cases $(n=50)$

\begin{tabular}{lll}
\hline & Mean \pm SD & Range \\
\hline Age (years) & $6.5 \pm 3.05$ & $3.20-10.90$ \\
Height SDS & $-3.12 \pm 0.2$ & $-2.15--4.21$ \\
-GV after Zn (cm/3 months) & $0.55 \pm 0.1$ & $0.1-2.23$ \\
-GV SDS after Zn & $+1.01 \pm 0.2$ & $-0.5-+2.11$ \\
- Weight SDS & $-1.88 \pm 0.62$ & $-2.01-+0.55$ \\
- BMl SDS & $-1.77 \pm 0.41$ & $-2.10--0.78$ \\
- Serum Zn ( $\mathrm{gg} / \mathrm{dl})$ & $56.76 \pm 7.90$ & $37.52-93.11$ \\
-Peak GH after insulin & $10.65 \pm 2.01$ & $7.61-13.20$ \\
stimulation (ng/ml) & & \\
-Peak GH after clonidine & $11.14 \pm 1.41$ & $6.92-14.11$ \\
stimulation (ng/ml) & & \\
- IGF-1 (ng/ml) & $96.72 \pm 11.5$ & $36.52-115.69$ \\
-IGF-1 SDS & $-2.46 \pm 0.11$ & $-3.22-+0.55$ \\
- IGFBP-3 (ng/ml) & $2436.12 \pm 392$ & $1195.45-3898.15$ \\
-BA (years) & $3.7 \pm 1.05$ & $1.81-9.25$ \\
-BA SDS & $-1.75 \pm 1.14$ & $-2.44-+0.22$ \\
\hline
\end{tabular}

Results are expressed as mean \pm SD and range, Zn: zinc, SDS: Standard deviation score, GV: Growth velocity, BMl: Body mass index, GH: Growth hormone, IGF-1: Insulin like growth factor-1, IGFBP-3: Insulin like growth factor binding protein-3, BA: bone age.

- Oral $\mathrm{Zn}$ sulfate (50 mg/day elemental $\mathrm{Zn}$ ) was given to all subjects for 3 months after which auxological assessment was repeated and serum samples were withdrawn to repeat all laboratory assays. In addition, growth velocity (GV) after 3 months of Zn therapy was calculated. GV is the variable that describes the patient's one year or 6 months or 3 months height velocity. GV SDS was calculated according to the norms of Tanner etal, 1966 [8].

\section{Statistical analysis}

The results were analyzed using the Statistical Package for the Social Science (SPSS) version number 10, Echosoft corp; USA, 2005. Description of quantitative variables was in the form of mean \pm standard deviation and range while that of qualitative variables was in the form of frequency and percentage. Student's t-test of 2 independent samples was used to compare 2 quantitative variables while Wilcoxon Signed Rank test was used to compare 2 dependent groups before and after $\mathrm{Zn}$ supplementation. Spearman correlation coefficient test (r-test) was used to rank different variables against each other either directly or indirectly. A p-value of $<0.05$ was considered significant.

\section{Results}

\section{Characteristics of studied cases}

Descriptive clinical, laboratory and radiological data of studied cases are presented in Table 1. Of the 50 studied cases, serum IGF-1 levels were below the normal age-
Table 2 Comparison of clinical, laboratory and radiological data among cases and controls

\begin{tabular}{|c|c|c|c|c|}
\hline & Cases & Controls & $\mathbf{t}$ & $p$ \\
\hline & $(\mathrm{N}=50)$ & $(\mathrm{N}=50)$ & & \\
\hline \multirow[t]{2}{*}{ Age (years) } & $6.5 \pm 3.05$ & $6.7 \pm 2.05$ & 1.2 & 0.11 \\
\hline & $(3.2-10.9)$ & $(3.5-10.8)$ & & \\
\hline \multicolumn{5}{|l|}{ Sex, $n(\%)$} \\
\hline Males & $27(54 \%)$ & $28(56 \%)$ & 1.11 & 0.23 \\
\hline Females & $23(46 \%)$ & $22(44 \%)$ & & \\
\hline \multirow[t]{2}{*}{ Height SDS } & $-3.12 \pm 0.2$ & $+1.04 \pm 0.5$ & 19.88 & $3<0.001^{* * *}$ \\
\hline & $(-2.15--4.21)$ & $(+0.99-+1.65)$ & & \\
\hline \multirow{2}{*}{$\begin{array}{l}\text { GV after Zn } \\
\text { (cm/3 months) }\end{array}$} & $0.55 \pm 0.1$ & $0.61 \pm 0.1$ & 0.82 & 0.11 \\
\hline & $(0.1-2.23)$ & $(0.2-3.13)$ & & \\
\hline \multirow[t]{2}{*}{ GV SDS } & $+1.01 \pm 0.2$ & $+1.21 \pm 0.1$ & 1.3 & 0.15 \\
\hline & $(-0.5-+2.11)$ & $(-0.3-+2.31)$ & & \\
\hline \multirow[t]{2}{*}{ Weight SDS } & $-1.88 \pm 0.62$ & $-1.02 \pm 0.71$ & 1.7 & 0.2 \\
\hline & $(-2.01-+0.55)$ & $(-1.20-+1.45)$ & & \\
\hline \multirow[t]{2}{*}{ BMI (kg/m2) } & $16.41 \pm 1.56$ & $17.51 \pm 0.52$ & 1.0 & 0.3 \\
\hline & $(14.33-20.12)$ & $(14.33-20.12)$ & & \\
\hline \multirow[t]{2}{*}{ BMI SDS } & $-1.77 \pm 0.41$ & $-1.02 \pm 0.31$ & 1.99 & 0.082 \\
\hline & $(-2.10--0.78)$ & $(-1.30-+0.23)$ & & \\
\hline \multirow[t]{2}{*}{ Serum Zn ( $\mu \mathrm{g} / \mathrm{dl})$} & $56.76 \pm 7.90$ & $136.70 \pm 8.10$ & 22.5 & $<0.001 * * *$ \\
\hline & $(37.52-93.11)$ & (123.17-149.50) & & \\
\hline \multirow{2}{*}{$\begin{array}{l}\text { Peak GH after insulin } \\
\text { stimulation (ng/ml) }\end{array}$} & $10.65 \pm 2.01$ & $14.25 \pm 3.01$ & 6.50 & $0.04 *$ \\
\hline & $(7.61-13.20)$ & $(10.91-18.30)$ & & \\
\hline \multirow{2}{*}{$\begin{array}{l}\text { Peak GH after } \\
\text { clonidine stimulation } \\
(\mathrm{ng} / \mathrm{ml})\end{array}$} & $11.14 \pm 1.41$ & $15.24 \pm 2.11$ & 6.81 & $0.041 *$ \\
\hline & $(6.92-14.11)$ & $(11.12-19.21)$ & & \\
\hline \multirow[t]{2}{*}{ IGF-1 (ng/ml) } & $96.72 \pm 11.5$ & $286.62 \pm 12.5$ & 12.86 & $5<0.001^{* * *}$ \\
\hline & $(36.52-115.69)$ & (198.72-325.19) & & \\
\hline \multirow[t]{2}{*}{ IGF-1 SDS } & $-2.46 \pm 0.11$ & $+1.46 \pm 0.21$ & 17.66 & $5<0.001^{* * *}$ \\
\hline & $(-3.22-+0.55)$ & $(+0.89-+1.85)$ & & \\
\hline \multirow[t]{2}{*}{ IGFBP-3 (ng/ml) } & $2436.12 \pm 392$ & $3936.22 \pm 194$ & 15.12 & $2<0.001^{* * *}$ \\
\hline & $\begin{array}{l}(1195.45- \\
3898.15)\end{array}$ & $\begin{array}{l}(3721.45- \\
4498.15)\end{array}$ & & \\
\hline \multirow[t]{2}{*}{-BA (years) } & $3.7 \pm 1.05$ & $6.8 \pm 1.6$ & 6.11 & $0.020^{*}$ \\
\hline & $(1.81-9.25)$ & $(3.31-11.25)$ & & \\
\hline \multirow[t]{2}{*}{$-B A$ SDS } & $-1.75 \pm 1.14$ & $+0.85 \pm 1.20$ & 13.24 & $4<0.001^{* * *}$ \\
\hline & $(-2.44-+0.22)$ & $(+1.04-+0.22)$ & & \\
\hline
\end{tabular}

Results are expressed as mean \pm SD and range frequency and percentage, ${ }^{*} \mathrm{p}<0.05,{ }^{* *} \mathrm{p}<0.01,{ }^{* * *} \mathrm{p}<0.001$, GHD: growth hormone deficiency, SDS: Standard deviation score, GV: growth velocity, Zn: zinc, BMI: Body mass index, Zn: zinc, GH: Growth hormone, IGF-1: Insulin like growth factor-1, IGFBP-3: Insulin like growth factor binding protein-3, BA: bone age.

matched reference ranges in $47(94 \%)$ while serum IGFBP-3 concentrations were below the normal agematched reference ranges in all children (100\%). In addition, GHD was diagnosed in 25 cases (50\%), that is, a peak $\mathrm{GH}$ of $<10 \mathrm{ng} / \mathrm{ml}$ by $2 \mathrm{GH}$ provocation tests. The 
Table 3 Comparison of clinical, laboratory and radiological data of studied cases with and without GHD

\begin{tabular}{|c|c|c|c|c|}
\hline & With GHD & Without GHD & $t$ & $p$ \\
\hline & $(\mathrm{N}=25)$ & $(\mathrm{N}=25)$ & & \\
\hline \multirow[t]{2}{*}{ Height SDS } & $-3.52 \pm 0.3$ & $-2.56 \pm 0.1$ & 6.11 & $0.043 *$ \\
\hline & $(-2.85--4.21)$ & $(-2.15--2.91)$ & & \\
\hline \multirow[t]{2}{*}{$\mathrm{GV}$ (cm/3 months) } & $1.21 \pm 0.2$ & $0.85 \pm 0.1$ & 5.99 & $0.041 *$ \\
\hline & $(0.7-2.23)$ & $(0.1-1.83)$ & & \\
\hline \multirow[t]{2}{*}{ GV SDS } & $+1.56 \pm 0.5$ & $+0.91 \pm 0.2$ & 7.12 & $0.030 *$ \\
\hline & $(+0.72-+2.11)$ & $(-0.5-+1.86)$ & & \\
\hline \multirow[t]{2}{*}{ Weight SDS } & $-1.68 \pm 0.12$ & $-1.58 \pm 0.52$ & 1.9 & 0.5 \\
\hline & $(-1.99-+0.55)$ & $(-2.01-+0.25)$ & & \\
\hline \multirow[t]{2}{*}{ BMI (kg/m2) } & $16.91 \pm 0.25$ & $17.31 \pm 0.46$ & 1.8 & 0.3 \\
\hline & $(15.56-18.12)$ & $(14.53-17.92)$ & & \\
\hline \multirow[t]{2}{*}{ BMI SDS } & $-1.81 \pm 0.10$ & $-1.72 \pm 0.32$ & 2.1 & 0.5 \\
\hline & $(-1.9--0.78)$ & $(-2.10--0.82)$ & & \\
\hline \multirow[t]{2}{*}{ Serum Zn ( $\mu \mathrm{g} / \mathrm{dl})$} & $45.71 \pm 2.9$ & $76.16 \pm 5.9$ & 18.12 & $<0.001 * * *$ \\
\hline & $(37.52-61.55)$ & $(39.12-93.11)$ & & \\
\hline \multirow{2}{*}{$\begin{array}{l}\text { Peak GH after insulin } \\
\text { stimulation(ng/ml) }\end{array}$} & $7.81 \pm 0.1$ & $11.61 \pm 1.01$ & 9.11 & $0.021 *$ \\
\hline & $(7.61-8.91)$ & $(10.55-13.20)$ & & \\
\hline \multirow{2}{*}{$\begin{array}{l}\text { Peak GH after } \\
\text { clonidine stimulation } \\
(\mathrm{ng} / \mathrm{ml})\end{array}$} & $7.14 \pm 0.12$ & $12.54 \pm 1.21$ & 10.16 & $0.01 *$ \\
\hline & $(6.92-8.53)$ & $(10.88-14.11)$ & & \\
\hline \multirow[t]{2}{*}{ IGF-1 (ng/ml) } & $46.78 \pm 6.5$ & $100.12 \pm 12.5$ & 16.22 & $<0.001 * * *$ \\
\hline & $(36.52-59.11)$ & $(72.55-115.69)$ & & \\
\hline \multirow[t]{2}{*}{ IGF-1 SDS } & $-2.72 \pm 0.10$ & $+0.38 \pm 0.21$ & 19.01 & $<0.001 * * *$ \\
\hline & $(-3.22--2.11)$ & $(-1.20-+0.55)$ & & \\
\hline \multirow[t]{2}{*}{ IGFBP-3 (ng/ml) } & $2006.22 \pm 92$ & $3445.11 \pm 292$ & 9.88 & $0.01 *$ \\
\hline & $\begin{array}{l}(1195.45- \\
2111.26)\end{array}$ & $\begin{array}{l}(3124.45- \\
3898.15)\end{array}$ & & \\
\hline \multirow[t]{2}{*}{$-B A$ (years) } & $2.8 \pm 1.0$ & $5.7 \pm 1.26$ & 8.15 & $0.03 *$ \\
\hline & $(1.81-5.9)$ & $(4 .-9.25)$ & & \\
\hline \multirow[t]{2}{*}{-BA SDS } & $-1.7 \pm 0.12$ & $-0.7 \pm 0.14$ & 11.22 & $0.01 *$ \\
\hline & $(-2.44-+0.01)$ & $(-1.14-+0.22)$ & & \\
\hline
\end{tabular}

Results are expressed as mean \pm SD and range, ${ }^{*} p<0.05$, ${ }^{* *} p<0.01$, ${ }^{* * *} p<0.001$, GHD: growth hormone deficiency, SDS: Standard deviation score, GV: growth velocity, BMI: Body mass index, Zn: zinc, GH: Growth hormone, IGF-1: Insulin like growth factor-1, IGFBP-3: Insulin like growth factor binding protein-3, BA: bone age.

mean GV of all studied cases after 3 months of $\mathrm{Zn}$ supplementation was $0.55 \pm 0.1$ (range:0.1-2.23) with a GV SDS of $+1.01 \pm 0.2$ (range: $-0.5-+2.11$, Table 1$)$.

\section{Cases versus controls}

Height SDS $(\mathrm{p}<0.001)$, serum $\mathrm{Zn}(\mathrm{p}<0.001)$, peak GH after insulin $(\mathrm{P}=0.04)$ and clonidine stimulation $(\mathrm{P}=0.041)$, IGF-1 $\quad(\mathrm{P}<0.001), \quad$ IGF-1 SDS $\quad(\mathrm{p}<0.001), \quad$ IGFBP-3 $(\mathrm{P}<0.001), \mathrm{BA}(\mathrm{p}=0.02)$ and BA SDS $(\mathrm{p}<0.001)$ were significantly lower among cases than controls. On the other
Table 4 Comparison of clinical, laboratory and radiological data of studied cases $(n=50)$ before and 3 months after $Z n$ supplementation

\begin{tabular}{|c|c|c|c|c|}
\hline & Before Zn & After Zn & $z$ & $\mathrm{p}$ \\
\hline \multirow[t]{2}{*}{ Height SDS } & $-3.12 \pm 0.2$ & $-1.87 \pm 0.1$ & 6.76 & $0.033^{*}$ \\
\hline & $(-2.15--4.21)$ & $(-2.0--3.11)$ & & \\
\hline \multirow[t]{2}{*}{ Weight SDS } & $-1.88 \pm 0.62$ & $-1.72 \pm 0.51$ & 1.83 & 0.21 \\
\hline & $(-2.01-+0.55)$ & $(-2.05-+0.66)$ & & \\
\hline \multirow[t]{2}{*}{$\mathrm{BMI}(\mathrm{kg} / \mathrm{m} 2)$} & $16.41 \pm 0.56$ & $16.58 \pm 0.22$ & 1.59 & 0.11 \\
\hline & $(14.33-18.12)$ & $(14.91-18.42)$ & & \\
\hline \multirow[t]{2}{*}{ BMI SDS } & $-1.77 \pm 0.41$ & $-1.58 \pm 0.32$ & 1.80 & 0.26 \\
\hline & $(-2.10--0.78)$ & $(-0.91--1.95)$ & & \\
\hline \multirow[t]{2}{*}{ Serum Zn $(\mu \mathrm{g} / \mathrm{dl})$} & $56.76 \pm 7.9$ & $148.25 \pm 15.4$ & 8.29 & $<0.001 * * *$ \\
\hline & $(37.52-93.11)$ & $(77.55-226.13)$ & & \\
\hline \multirow{2}{*}{$\begin{array}{l}\text { Peak GH after } \\
\text { insulin stimulation } \\
\text { (ng/ml) }\end{array}$} & $10.65 \pm 2.01$ & $12.10 \pm 1.13$ & 2.10 & 0.081 \\
\hline & $(7.61-13.20)$ & $(8.90-14.82)$ & & \\
\hline \multirow{2}{*}{$\begin{array}{l}\text { Peak GH after } \\
\text { clonidine } \\
\text { stimulation (ng/ml) }\end{array}$} & $11.14 \pm 1.41$ & $12.99 \pm 1.22$ & 1.15 & 0.090 \\
\hline & $(6.92-14.11)$ & $(8.90-14.82)$ & & \\
\hline \multirow[t]{2}{*}{ IGF-1 (ng/ml) } & $96.72 \pm 11.5$ & $177.50 \pm 9.06$ & 7.12 & $<0.010^{* *}$ \\
\hline & (36.52-115.69) & $(42.65-213.66)$ & & \\
\hline \multirow[t]{2}{*}{ IGF-1 SDS } & $-2.46 \pm 0.11$ & $-0.91 \pm 0.43$ & 9.16 & $<0.010^{* *}$ \\
\hline & $(-3.22-+0.55)$ & $(-2.95-+1.10)$ & & \\
\hline \multirow[t]{2}{*}{ IGFBP-3 (ng/ml) } & $2436.12 \pm 392$ & $2856.30 \pm 411$ & 5.90 & $0.042 *$ \\
\hline & $(1195.45-3898.15)$ & ) (1341.10-3912.51 & & \\
\hline \multirow[t]{2}{*}{-BA (years) } & $3.7 \pm 1.05$ & $4.12 \pm 1.32$ & 1.25 & 0.081 \\
\hline & $(1.81-9.25)$ & $(2.13-9.81)$ & & \\
\hline \multirow[t]{2}{*}{-BA SDS } & $-1.7 \pm 1.14$ & $-1.5 \pm 1.21$ & 0.13 & 0.35 \\
\hline & $(-2.44-+0.22)$ & $(-2.10-+0.65)$ & & \\
\hline
\end{tabular}

Results are expressed as mean $\pm S D$ and range, ${ }^{*} p<0.05$, ${ }^{* *} p<0.01$,

***p $<0.001$, Zn: zinc, SDS: Standard deviation score, BMI: Body mass index, GH: Growth hormone, IGF-1: Insulin like growth factor-1, IGFBP-3: Insulin like growth factor binding protein-3, BA: bone age.

hand, other clinical parameters and; GV and GV SDS did not differ between both groups ( $p>0.05$, Table 2).

\section{Cases with GHD versus cases without GHD}

Height SDS $(\mathrm{p}=0.043)$, serum $\mathrm{Zn}(\mathrm{p}<0.001)$, peak $\mathrm{GH}$ after insulin $(\mathrm{P}=0.021)$ and clonidine stimulation $(\mathrm{P}=0.01)$, IGF-1 $\quad(\mathrm{P}<0.001), \quad$ IGF-1 SDS $\quad(\mathrm{p}<0.001), \quad$ IGFBP-3 $(P=0.01)$, BA $(p=0.03)$ and BA SDS $(p=0.01)$ were significantly lower among cases with GHD when compared to those without GHD. On the other hand, cases with GHD had significantly higher GV $(p=0.041)$ and GV SDS $(p=0.03)$ when compared to those without GHD (Table 3).

\section{Characteristics of cases before and 3 months after $\mathrm{Zn}$ supplementation}

On comparing clinical, laboratory and radiological parameters among all studied patients before and 3 months 

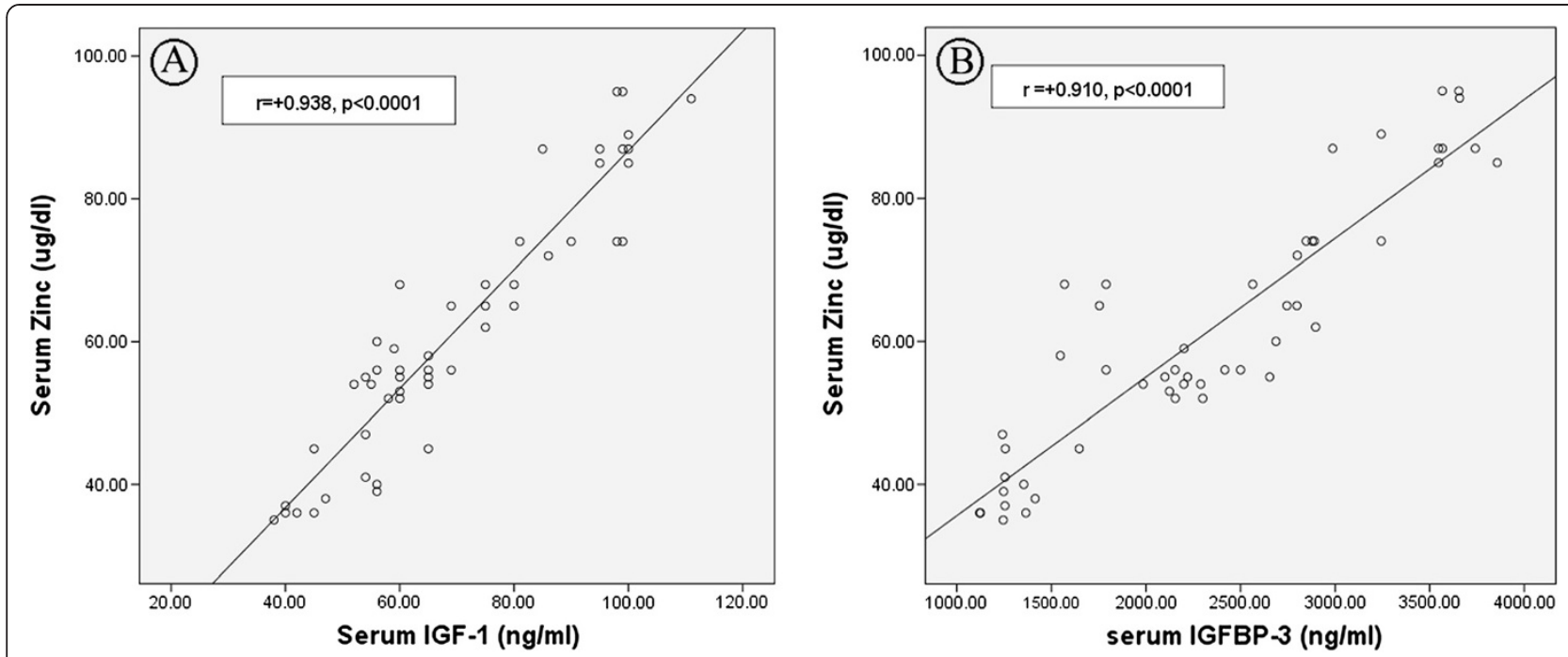

Figure 1 Correlations between serum zinc and each of serum IGF-1 (Figure 1A) and serum IGFBP-3 (Figure 1B).

after Zn supplementation, there were significant increases in height SDS $(\mathrm{P}=0.033)$, serum $\mathrm{Zn}(\mathrm{P}<0.001)$, IGF-1 $(\mathrm{P}<0.01)$, IGF-1 SDS $(\mathrm{p}<0.01)$ and IGFBP-3 $(\mathrm{P}=0.042)$ while other clinical and laboratory parameters did not differ 3 months after $Z n$ supplementation ( $P>0.05$, Table 4).

Serum $\mathrm{Zn}$ levels rose in all patients but reached normal reference ranges in 32 cases (64\%), serum IGF-1 levels rose in 30 cases $(60 \%)$ but reached normal reference ranges in 20 cases (40\%) and serum IGFBP-3 levels rose in 20 cases (40\%) but reached normal reference ranges in 11 cases (22\%). There were no adverse effects other than mild nausea in some patients during the $\mathrm{Zn}$ supplementation period.

\section{Relation between serum $\mathrm{Zn}$ and each of laboratory and radiological parameters among studied cases}

There were significant positive correlations between serum Zn level and each of serum IGF-1 $(r=0.938, p<0.0001$, Figure 1A), IGF-1 SDS $(\mathrm{r}=0.81, \mathrm{p}<0.001)$ and IGFBP-3 levels $(p=0.910, p<0.0001$, Figure $1 B)$ before $Z n$ supplementation. On the other hand, serum $\mathrm{Zn}$ did not correlate significantly with peak stimulated $\mathrm{GH}$ after insulin induced hypoglycemia $(r=0.17, p=0.31)$ and clonidine stimulation $(\mathrm{r}=0.13, \mathrm{p}=0.23)$, BA $(\mathrm{r}=0.15, \mathrm{p}=0.13)$ and BA SDS $(\mathrm{r}=0.11, \mathrm{p}=0.22)$.

\section{Discussion}

$\mathrm{Zn}$ deficiency in humans is widespread throughout the world especially in developing countries. In Egypt, growth retardation and short stature due to $\mathrm{Zn}$ deficiency are commonly observed. This could be explained by the fact that intakes of animal products and animal protein are very low due to low socio-economic status of the population. In addition, $\mathrm{Zn}$ intake is not only low, but its bioavailability is poor because of the high phytate, fiber and tea content of the diet among Egyptian population [15]. Zn deficiency during the period of growth results in growth failure and lack of gonadal development, especially in males. Other effects of $\mathrm{Zn}$ deficiency include skin changes, poor appetite, mental lethargy, delayed wound healing, neurosensory disorders and cellmediated immune disorders [1].

Cesur et al, 2009 [16] found that serum IGF-1 and IGFBP-3 were below normal reference ranges in $96.6 \%$ and $100 \%$ of their short children with $\mathrm{Zn}$ deficiency which is close to our findings $(94 \%$ and $100 \%$ respectively). It is not known what mechanism is responsible for growth retardation in $\mathrm{Zn}$ deficiency and how $\mathrm{Zn}$ therapy stimulates growth in children [1]. Moreover, the exact mechanism of the effects of $\mathrm{Zn}$ deficiency and $\mathrm{Zn}$ supplementation on GH secretion, serum IGF-1 levels, and growth is not well delineated [3].

The current study revealed significant increases in height SDS, GV and its SDS; serum Zn, IGF-1 and IGFBP-3 after 3 months of $\mathrm{Zn}$ therapy with no difference in GV between $\mathrm{Zn}$ deficient cases and non $\mathrm{Zn}$-deficient controls. Our findings were supported by other studies $[3-5,17,18]$ who reported that $\mathrm{Zn}$ supplementation was effective for inducing growth in short children with $\mathrm{Zn}$ deficiency in a rate similar to that in healthy children. However, in some studies, this effect was not observed [6,7]. Ninh et al [19] showed that Zn supplementation increased both weight and height after five months compared with placebo treatment but this was not the case in our study concerning the weight. According to these findings, some studies [19-21] 
suggested that the growth- stimulating effect of $\mathrm{Zn}$ might be mediated through changes in circulating IGF-1 levels.

On the other hand, an experimental study in rats [22] showed that restoration of normal circulating levels of IGF-1 and IGFBP-3 by recombinant IGF-1 infusion failed to reverse the growth retardation induced by $\mathrm{Zn}$ deficiency. They suggested that growth retardation related to $\mathrm{Zn}$ deficiency is caused not only by low serum IGF-1 concentrations, but also by inhibition of the anabolic actions of IGF-1. Moreover, it has been shown that Zn deficiency also leads to alterations in the distribution of serum IGFBPs, in addition to lower circulating IGF-1 concentrations [21]. This theory was further supported by the strong positive correlations between serum Zn and each of IGF-1, IGF-1 SDS and IGFBP-3 levels reported in our study. In addition, other studies $[20,21]$ suggested a state of GH resistance rather than GHD in case of Zn deficiency.

In addition, Imamoglu et al [23] reported that $\mathrm{Zn}$ supplementation increased IGF-1 and IGFBP-3 in non$\mathrm{Zn}$-deficient children with idiopathic short stature. They suggested several explanations for this observation. First, Zn supplementation may have increased the sensitivity to endogenous GH. Secondly, Zn supplementation may have increased the physiological GH secretion (i.e. sleep associated) without altering $\mathrm{GH}$ response to pharmacological stimulation. Alternatively, $\mathrm{Zn}$ may have non-GH mediated (direct) effects on the synthesis of IGF-1 and IGFBP-3. Support for the first hypothesis comes from animal studies in which ionic $\mathrm{Zn}$ exerted a dose dependent stimulation of hGH specific binding to isolated rat adipocytes [24]. Furthermore, $\mathrm{Zn}$ ion was found to induce dimerization of human GH [25] and to enhance the bioactivity of hGH [26]. In vivo studies demonstrated that $\mathrm{Zn}$ deficiency markedly decreased expression of IGF-1 and GH receptor genes in the liver of growing rats [27]. Support for the third hypothesis comes from the observation that Zn deficiency causes a post-receptor defect in GH action, and a decrease in IGF-1 gene expression which is reversed by $\mathrm{Zn}$ supplementation but not by GH administration [28]. This hypothesis was further supported in our study by the finding of higher GV after 3 months of Zn supplementation in GH-deficient than non GH-deficient, both having Zn deficiency.

On the other hand, some reports found increased GH response to pharmacological stimulation after $\mathrm{Zn}$ supplementation in Zn-deficient children [5,21,29,30] which was not the case in our study. Siklar et al [30] suggested that during $\mathrm{GH}$ treatment in $\mathrm{GH}$ deficient children, $\mathrm{Zn}$ status should be evaluated, as severe $\mathrm{Zn}$ deficiency could decrease the response to $\mathrm{GH}$ treatment which is improved with correction of Zn deficiency [30].

In the current study, after 3 months of $\mathrm{Zn}$ supplementation, serum $\mathrm{Zn}$ levels rose in all patients but reached normal reference ranges in 32 cases (64\%), serum IGF-1 levels rose in 30 cases $(60 \%)$ but reached normal reference ranges in 20 cases $(40 \%)$ and serum IGFBP-3 levels rose in 20 cases $(40 \%)$ but reached normal reference ranges in 11 cases $(22 \%)$. Similar results were obtained by Cesur et al, 2009 [16] who confirmed the fact that Zn supplementation affects serum IGF-1 and IGFBP-3 levels in children with $\mathrm{Zn}$ deficiency but due to the fact that $\mathrm{Zn}$ supplementation was given for only two months, the increases in serum IGF-1 and IGFBP-3 levels were still lower than the normal range in most of their children; therefore, they suggested that $\mathrm{Zn}$ supplementation may be necessary for longer periods.

\section{Conclusions}

In conclusion, serum IGF-1 and IGFBP-3 levels were found to be low in short children with $\mathrm{Zn}$ deficiency, and increased after $\mathrm{Zn}$ supplementation for 3 months but their levels were still lower than the normal reference ranges in most children; therefore, $\mathrm{Zn}$ supplementation may be necessary for longer periods. In addition, GV did not differ between $\mathrm{Zn}$-deficient and healthy children with a better GV observed in GH-deficient children. Further studies on larger population scales and for longer periods are warranted to explore the mechanism by which $\mathrm{Zn}$ deficiency affects GH- IGF axis and to assess the effect of $\mathrm{Zn}$ supplementation on it.

\section{Competing interests}

All authors declare that they do not have any financial or non financial competing interests.

\section{Author details}

'Department of Pediatrics, Ain Shams University, 36 Hisham Labib street, off Makram Ebeid street, Nasr City, Cairo, Egypt. ${ }^{2}$ Department of Clinical Pathology, Faculty of Medicine, Ain Shams University, Cairo, Egypt.

${ }^{3}$ Department of Clinical and Chemical Pathology, National Research Center, Cairo, Egypt.

\section{Authors' contributions}

RTH conceived the study, participated in its design and coordination, drafted the manuscript, collected demographical and clinical data of the children and gave final approval of the version to be published. AlH participated in its design and coordination, carried out the laboratory studies and performed the statistical analysis. MTS carried out the laboratory studies and helped in the statistical analysis and drafting of manuscript. All authors read and approved the final manuscript.

\section{Authors' information}

- RTH: Assistant Professor of Pediatrics and Pediatric Endocrinology, Ain Shams University, Cairo, Egypt.

- AlH: Lecturer of Clinical Pathology, Ain Shams University, Cairo, Egypt. -MTS: Lecturer of Clinical and Chemical Pathology, National Research Center, Cairo, Egypt.

Received: 28 September 2011 Accepted: 24 May 2012 Published: 24 May 2012

\section{References}

1. Prasad AS: Zinc: an overview. Nutrition 1995, 11:93-99.

2. Underwood LE, Thissen JP, Lemozy S, Ketelslegers JM, Clemmons DR: Hormonal and nutritional regulation of IGF-I and its binding proteins. Horm Res 1994, 42:145-151. 
3. Nakamura T, Nishijama S, Futagoishi Y, Matsuda I, Higashi A: Mild to moderate zinc deficiency in short children: effect of zinc supplementation on linear growth velocity. J Pediatr 1993, 123:65-69.

4. Walravens PA, Hambidge KM, Koepfer DM: Zinc supplementation in infants with a nutritional pattern of failure to thrive: a double-blind, controlled study. Pediatrics 1989, 83:532-538.

5. Nishi Y, Hatano S, Aihara K, Fujie A, Kihara M: Transient partial GH deficiency due to zinc deficiency. Am Coll Nutr 1989, 8:93-97.

6. Friis $H$, Ndhlovu P, Mduluza T, Kaondera K, Sandstrom $\beta$, Michaelsen KF, Vennervald BJ, Christensen NO: The impact of zinc supplementation on growth and body composition: a randomised, controlled trial among rural Zimbabwean school children. Eur J Clin Nutr 1997, 51:38-45.

7. Hershkowitz E, Printzman L, Segev Y, Levy J, Philip M: Zinc supplementation increases the level of serum IGF-I but does not promote growth in infants with nonorganic failure to thrive. Horm Res 1999, 52:200-204

8. Tanner JM, Whitehouse RH, Takaishi M: Standards from birth to maturity for height, weight, height velocity, and weight velocity: British children, 1965. Arch Dis Child 1966, 41:454-613.

9. Cole TJ: A chart to link child centiles of body mass index, weight and height. Eur J Clin Nutr 2002, 56:1194-1199.

10. Tanner JM, Whitehouse RH: Clinical longitudinal standards for height, weight, height velocity, weight velocity and stages of puberty. Arch Dis Child 1976, 51:170-179.

11. Lampugnani L, Maccheroni M, Rotunno T: A simple colorimetric method for the zinc assay in blood. Anal Lett 1990, 23:1665-1683.

12. Elmlinger $M W$, Kühnel W, Weber MM, Ranke MB: Reference ranges for two automated chemiluminescent assays for serum insulin-like growth factor I (IGF-I) and IGF-binding protein 3 (IGFBP-3). Clin Chem Lab Med 2004, 42:654-664.

13. Greenwood FC, Landon J, Stamp TCB: The plasma sugar, free fatty acid, cortisol, and growth hormone response to insulin in control subjects. J Clin Invest 1966, 45:429-436.

14. Greulich WW, Pyle SI: Radiographic atlas of skeletal development of the hand and wrist. Stanford, California: Stanford University Press; 1959.

15. Neumannn CG, Harrison GG: Onset and evolution of stunting in infants and children. Examples from the Human Nutrition Collaborative Research Support Program. Kenya and Egypt studies. Eur J Clin Nutr 1994, suppl 1:s90-s102.

16. Cesur Y, Yordam N, Dogan M: Serum Insulin-like Growth Factor-I and Insulin-like Growth Factor Binding Protein-3 Levels in Children with Zinc Deficiency and the Effect of Zinc Supplementation on these Parameters. J Pediatr Endocrinol Metab 2009, 22:1137-1143.

17. Sayeg Porto MA, Oliveira HP, Cunha AJ, Miranda G, Guimaraes MM, Oliveira WA, Dos Santos DM: Linear growth and zinc supplementation in children with short stature. J Pediatr Endocrinol Metab 2000, 13:1121-1128.

18. Ghavami-Maibodi SZ, Collipp PJ, Castro-Magana M, Stewart C, Chen SY: Effect of oral zinc supplements on growth, hormonal levels, and zinc in healthy short children. Ann Nutr Metab 1983, 27:214-219.

19. Ninh NX, Thissen JP, Collette L, Gerard G, Khoi HH, Ketelslegers JM: Zinc supplementation increases growth and circulating insulin-like growth factor I (IGF-I) in growth-retarded Vietnamese children. Am J Clin Nutr 1996, 63:514-519.

20. Oner G, Bhaumick B, Bala RM: Effect of zinc deficiency on serum somatomedin levels and skeletal growth in young rats. Endocrinology 1984, 114:1860-1863.

21. Clegg MS, Keen CL, Donovan SM: Zinc deficiency induced anorexia influences the distribution of serum insulin-like growth factor-binding proteins in the rat. Metabolism 1995, 44:1495-1501.

22. Ninh NX, Mailer D, Verniers J, Lause P, Ketelslegers JM, Thissen JP: Failure of exogenous IGF-I to restore normal growth in rats submitted to dietary zinc deprivation. J Endocrinol 1998, 159:211-217.

23. Imamoglu S, Bereket A, Turan S, Taga Y, Haklar G: Effect of zinc supplementation on growth hormone secretion, IGF-I, IGFBP-3, somatomedin generation, alkaline phosphatase, osteocalcin and growth in prepubertal children with idiopathic short stature. J Pediatr Endocrinol Metab 2005, 18:69-74.

24. Herington AC: Effect of zinc on the binding and action of $\mathrm{GH}$ in isolated rat adipocytes. Biochem Int 1985, 11:853-862.

25. Cunningham BC, Mulkerrin MG, Wells JA: Dimerization of human growth hormone by zinc. Science 1991, 253:545-548.
26. Dattani MT, Hindmarsh PC, Brook CG, Robinson IC, Weir T, Marshall NJ: Enhancement of GH bioactivity by zinc in the eluted stain assay system. Endocrinology 1993, 133:2803-2808.

27. McNall AD: The impaired growth induced by zinc deficiency in rats is associated with decreased expression of the hepatic IGF-I and GH receptor genes. J Nutr 1995, 125:874-879.

28. Ninh NX, Thissen JP, Maiter D, Adam E, Mulumba K, Ketelslegers JM: Reduced liver IGF-I gene expression in young zinc deprived rats is associated with a decrease in liver GH receptors and serum GHBP. J Endocrinol 1995, 144:449-456.

29. Collip PJ, Castro Magana PJ, Petroviz $\mu$, Thomas J, Cheruvanky T, Chen SY, Sussman H: Zinc deficiency: improvement in growth and growth hormone levels with oral zinc therapy. Ann Nutr Metab 1982, 26:287-290.

30. Siklar Z, Tuna C, Dallar Y, Tanyer G: Zinc deficiency: a contributing factor of short stature in growth hormone deficient children. J Trop Pediatr 2003, 49:187-188.

doi:10.1186/1824-7288-38-2

Cite this article as: Hamza et al:: Effect of zinc supplementation on growth Hormone Insulin growth factor axis in short Egyptian children with zinc deficiency. Italian Journal of Pediatrics 2012 38:21.

\section{Submit your next manuscript to BioMed Central and take full advantage of:}

- Convenient online submission

- Thorough peer review

- No space constraints or color figure charges

- Immediate publication on acceptance

- Inclusion in PubMed, CAS, Scopus and Google Scholar

- Research which is freely available for redistribution 